\title{
Strategies to Improve Teacher-Student Interactions in Senior Schools in Western China*
}

\author{
LIU Li-ping \\ Leshan Normal University, Leshan, China
}

\begin{abstract}
Teacher-student interaction is the main interactive form in senior English teaching in China, however, the quality of which should be improved a lot. This paper, based on the author's prior investigation and research, discusses the strategies to improve teacher-student interactions from the theoretical and practical perspectives. The strategies are as the followings: emphasis on meaning-focused interaction, improvement of teachers' questioning strategies and encouragement of students' initiation of questions, teachers' providing TL input, teacher development, the improvement in assessment systems, etc. This paper aims to make teacher recognize the importance and necessity of improving the quality of teacher-student interactions and do actions to promote students' learning and thinking abilities and the whole development as a human being.
\end{abstract}

Keywords: teacher-student interaction, senior English teaching in Western China, strategies, form-focused interaction, teacher development

\section{Introduction}

In the article, Research on Teacher-Student Interaction in Senior Schools English Teaching in Western China published in US-China Foreign Language (LIU, 2016, pp. 340-350), the author analyzes the problems and illustrates the current situations in teacher-student interaction in senior English teaching in Western China. In this article, the author continues to discuss the topic from the theory to practice and put forward some strategies and techniques to improve the quality of teacher-student interaction in English teaching in Western China.

As mentioned in the last paper, to some degree, the large-scale class decides that the main form of interactions in Western China is teacher-student interaction. And the main reasons to cause the low quality interaction are as the following: First, exam-oriented education leads teachers to focus on the transmission of English knowledge rather than learning for communication. Second, teachers' beliefs about English language and language teaching greatly affect their teaching behaviors, e.g., if they regard English as a tool or as a compulsory course tested in the College Entrance Examination, they will emphasize on the teaching of the English forms, not meaning. Third, in teacher-directed interaction, students' talk time and initiation of questions are restricted, which constraints their creative thinking and hinders their thinking ability. Fourth, Teachers' quality and competence also influence the efficiency of classroom interactions, e.g., their theoretical levels, English competence, their use of techniques, resources, media, etc. The assessment system also has an

\footnotetext{
* Acknowledgements: This paper is one of the research results of a teaching reform project in Center for Teacher Education Research at Sichuan Province: The Study of Cultivations on Pre-service Teachers of English Under Teacher Qualification Registration System (TER2014-009).

LIU Li-ping, professor, M.A., School of Foreign Languages, Leshan Normal University.
} 
influence on the interactions, if the scores or the enrollment rate to the universities are only used to evaluate whether the school is qualified or not, teachers will spend more time in testing their students, not in cultivating students' communicative abilities in English. This paper puts forward some strategies to improve the qualities of teacher-student interactions in Western China.

\section{Improvements of Teacher-Student Interaction}

According to Johnson, teaching and learning is an interactive process between teachers' and students' shared understanding, then how students interpret what teachers say and do will also shape the patterns of classroom communication (Johnson, 2000, p. 12). Malamah-Thomas illustrates the mutual reactions between the teacher and the students as an interactive activity between reaction and action through methodological device and feedback recycling (Malamah-Thomas, 1987, p. 39).

\section{Emphasis on Meaning-Focused Interaction}

Compared with form-focused interaction, meaning-focused interaction refers to the focus on the understanding of meaning in teaching English rather than on the forms of the language. The ideas of Second Language Acquisition (SLA) emphasize on the importance of moving students from noticing the language to understanding it and using it appropriately. Only when English is used in some contexts or situations can the learners understand it better. Senior English teachers can adopt some ways to enhance meaningful learning. Interaction can be a process of teaching no matter what teachers teach. Taking grammar teaching as an example, it is believed that grammar plays an important role in language teaching and learning. Interaction does not preclude the learning of the grammatical system of English. We can interact better if we know the syntactic choices while we are speaking. The problem is that many senior high school English teachers still favor the more traditional presentation of a rule followed by practice. Specifically speaking, they use a deductive way by giving the grammatical rules and more Chinese sentences to their students for translation. River's idea (River, 2000 , p. 13) sheds some light on grammar teaching. He means that teaching grammar is the process of interaction in which students can be stimulated to learn grammar actively without feeling bored and tired. Grammar is to be discovered and so grammatical awareness will emerge naturally from communicative interaction that has meaning. Teachers can use an inductive way to teach grammar by providing more examples to illustrate the grammatical rules and making students to perform the rules in some situations and creative contexts. Teachers can correct students' errors in the process of conversation naturally and students can master grammar unconsciously in communicative interactions.

\section{More Student Talk Time}

Teachers' questioning strategies. The initiation of interaction by the teacher is the most important factor to create an interactive classroom. Usually teachers initiate interaction by asking questions, so improving the quality of questioning is crucial. Brown suggests teachers develop a repertoire of questioning strategies. Appropriate questioning can fulfill many different functions. Teachers' questions give students opportunities to produce comfortable language. They can serve to initiate a chain reaction of student interaction among themselves. They give teachers feedback about students' comprehension. They also provide students with opportunities to find out what they think by hearing what they say (Brown, 2001a, p. 165). Brown also suggests many effective ways of questioning: Knowledge questions, application questions, inference questions, analysis questions, and synthesis questions will be used. 
English teachers can use these questioning strategies to stimulate students to think more carefully and deeply and talk more. In China, more knowledge questions are asked and students answer "Yes" or "No", which are called close-ended questions. While open-ended questions that allow many possible answers can train students thinking abilities, so more other kinds of questions are encouraged. More open-ended questions can stimulate students to speak more. Students can explore the problems and express their ideas, opinions, feelings, and reactions bravely and freely. In all, interaction between teachers and students can be strengthened.

Students' initiation of questions. According to Littlewood, learners must create the interaction by themselves on the basis of their roles and the meanings that arise, rather than perform in ways that have been predetermined by the teacher (Littlewood, 2000, p. 50).

It is teacher's duty to create a stress-free learning environment where students feel able and confident, not threatened by failure. Students are free to put forward questions without being scolded or blamed by teachers even if the questions are funny. Students are encouraged to think actively in class. Whenever they have new ideas, they can speak out bravely. A good way is that teachers can ask students to discuss the questions in their groups in class or after class, and the fierce discussion can bring new ideas or solutions to the questions, which can motivate students to think more deeply. Students' initiation of questions improves the quality of teacher-student interaction, which promotes teaching and learning, and the most important thing is to challenge teachers, who must continue learning to meet the needs of students and the developing society.

\section{Providing More TL Comprehensible Input}

One aspect of interaction is students' interaction with the TL (target language), so providing more TL can promote students to interact with the TL. English teachers play an important role in providing the TL. There are many forms of TL. English teachers in senior schools can make full use of them.

Apart from textbooks, teachers can provide as many as authentic materials for students as possible. More authentic listening, reading, writing materials, print, digitalization, text or tape can be supplied to the students, which are likely to motivate learners and promote acquisition; if they are used in sufficient quantities, they can contribute to language immersion. Students are encouraged to read aloud, which is the process of interaction with the materials; they are also encouraged to discuss with the teacher and their classmates and to express their own ideas, opinions, and feelings in English. More input of authentic materials can promote students to interact with the TL.

Teachers' use of English to explain the texts can increase students' English input, which can create an atmosphere of learning English and facilitate students' ability to think in English. Modern technology can be fully used in English teaching to enhance learning. Technology is now an indispensable tool, which can engage students in real-world interactions with each other. Walberg's studies of 377 examples of research (Walberg, 1991, pp. 25-70) found that computer-assisted instruction coupled with classroom teaching is superior to ordinary classroom instruction without computer assistance.

\section{Teacher Development}

Teacher development plays an important part in improving the quality of teacher-student interaction. Teaching efficiency of the teacher directly affects students' learning quality.

These years, the research on teacher development has drawn both the researchers' and teachers' attention. Jane Willis and Dove Willis (2002) elaborate great changes and challenges in language teaching and provide us with specific ways to develop expertise through experience. David Gardner and Lindsay Miller propose that 
learners' self-access language learning requires changes in the role of teachers and the teachers' beliefs about the language and students. Because teachers' beliefs directly affect the way they teach and students' beliefs affect the way they study (Gardner \& Miller, 2002, p. 37). Brown points out the importance of teacher development by calling it "Lifelong Learning" and he shows us many ways used to improve teacher quality: Classroom observation and classroom research, also called action research (Brown, 2001b, pp. 425-445). Harmer describes the specific methods in classroom research and points out the importance of cooperative development and the way of keeping teaching fresh in professional life. A good teacher is a good observer in his teaching and always likes to get feedback from their students (Harmer, 2001, pp. 344-350) (e.g., Lightbown, P. M., Spada, N., \& Richards J. C.).

How can teachers of English as a Foreign Language develop their competency to become true professionals in China? The shift of a teacher's notions is crucial, as the advanced notion can help teachers to adopt suitable methods according to learners' needs and cultural background, to offer more comprehensible input to learners, and to provide more opportunities for the learners to practice English. This depends on teachers' further learning.

Teacher's professional development is closely connected with the development of education. In China, teachers are improving themselves to meet new challenges. In recent years, many kinds of training courses: Long-term or short-term, pre-service and in-service courses, face to face and online training courses, and blended training courses have been provided to help teachers further their education. There are different forms of teacher development work-shops established for English teachers to improve their knowledge, theoretical levels, and abilities in doing classroom research, such as the National Training Programme (The Education Ministry of P.R.C., 2010). Compared with the training courses for teacher development, teacher's self-development is more emphasized; teachers should have the goal of life-long learning and cultivate their research abilities.

Teachers can use eclectic methods, such as communicative activities, as it offers real learning benefits and initiate interaction between a teacher and students or among the students to involve as many as students in learning.

\section{Improvement of Assessment System}

The New National English Curriculum for Senior English teaching (The Ministry of Education in P.R.C., 2003, p. 1) has been practiced for 13 years and was revised in 2011, which emphasizes the unity of humanism and toolism of English language. The goal of the curriculum is to increase the awareness of cultural differences between the East and the West. And the assessment should be geared to stimulating students' interest and cultivating their autonomy in learning. The system includes both formative and summative assessment. Formative assessment is emphasized, which requires teachers to pay more attention to students' learning process, such as their learning strategies, needs, interests, affects, confidence, and healthy personalities. The teachers' role is to facilitate the overall development of students in language learning, physical and mental growth and train students to be ready for future learning and life-long learning. Summative assessment focuses on assessing students' language ability by testing students. Some progress has been made these years; however, there is a long way to cover to change the current situation of "examination-oriented education".

Improvement of assessment system is the crucial element to promote classroom interaction. Once more attention is given to formative assessment, marking will not be the only thing to which teachers attach 
importance. Teachers' attention will be on students' full development. In teaching English, teachers will adopt interactive teaching to realize this goal. The adoption of interactive teaching can arouse students' learning interests and motivation, as a result, there will be a shift from rote and individual learning to cooperative learning and at last students' full development can be achieved.

\section{Conclusion}

Summarizing the discussions above, teacher-student interaction is important in senior English teaching in China, especially in Western China. Teacher professional development plays a crucial role in improving the quality of it, as English teachers' language competence as well as their beliefs, notions, attitudes towards English language, and teaching will influence their decisions and strategies in operating teacher-student interaction. Besides, the assessment system also affects the quality of it. Nowadays, our government pays more attention to teacher training and tries to improve the quality of teachers. We are confident in improving the learning efficiency, cultivating students thinking abilities, and promoting their physical and mental development.

\section{References}

Brown, H. D. (2001a). Teaching by principle: An interactive approach to language pedagogy (p. 165). Beijing: Foreign Language Teaching and Research Press.

Brown, H. D. (2001b). Teaching by principle: An interactive approach to language pedagogy (pp. 425-445). Beijing: Foreign Language Teaching and Research Press.

Bruner, J. (1978). The role of dialogue in language acquisition. In A. Sinclair and R. Javella (Eds.), The child's conception of language (pp. 241-256). New York: Springer-Verlag.

Gardner, D., \& Miller, L. (2002). Establishing self-access-From theory to practice (p. 37). Shanghai: Shanghai Foreign Language Education Press.

Harmer, J. (2001). The practice of English language teaching (pp. 344-350). Harlow: Pearson Education Limited.

Johnson, K. E. (2000). Understanding communication in second language classrooms (p. 12). Beijing: Foreign language Teaching and Research Press.

Littlewood, W. (2000). Communication language teaching (p. 50). Beijing: Foreign language Teaching and Research Press.

LIU, L. P. (2016). Research on teacher-student interaction in Senior Schools English Teaching in Western China. US-China Foreign Language, 14(5), 340-350.

Malamah-Thomas, A. (1987). Classroom interaction (p. 39). Oxford: Oxford University Press.

Rivers, W. M. (2000). Interactive language teaching (p. 13). Beijing: Foreign language Teaching and Research Press.

The Education Ministry of P.R.C. (2003). English curriculum standards for general high school (Experimental Version, p. 1). Beijing: People's Education Publishing Press.

The Education Ministry of P.R.C. (2010). National training programme (2010)—The notices of the implement details about research and studies team project.

Walberg, H. J. (1991). Improving school science in advanced and developing countries. Review of Educational Research, 61(1), 25-69.

Willis, J., \& Willis, D. (Eds.). (2002). Challenge and change in language teaching. Shanghai: Shanghai Foreign Languages Education Press. 